\title{
Investigation of the Behaviors of Users' Who Shop from E-Commerce Sites
}

\section{E-Ticaret Sitelerinden Alışveriş Yapan Kullanıcıların Davranışlarının İncelenmesi}

\author{
Selçuk Kıran ${ }^{1}$ (D), Berkay Alan² (1), İlkim Ecem Emre ${ }^{3}$ (1)
}

${ }^{1}$ Asst. Prof., Marmara University, Faculty of Business Administration, Department of Management Information Systems, Istanbul, Turkey

${ }^{2}$ Marmara University, Faculty of Business Administration, Department of Management Information Systems, Istanbul, Turkey ${ }^{3}$ Res. Asst., Marmara University, Faculty of Business Administration, Department of

Management Information Systems, Istanbul, Turkey

ORCID: S.K. 0000-0001-6088-2701;

B.A. 0000-0001-9503-3873

I.E.E. 0000-0001-9507-8967

Corresponding author:

Illkim Ecem EMRE

Marmara University, Faculty of Business

Administration, Department of Management

Information Systems, Istanbul Turkey

E-mail address: ecem.emre@marmara.edu.tr

Submitted: 03.03 .2021

Revision Requested: 06.05.2021

Last Revision Received: 27.07 .202

Accepted: 27.07.2021

Published Online: 22.09.2021

Citation: Kiran, S., Alan, B., \& Emre, I. E. (2021). Investigation of the behaviors of users' who shop from e-commerce sites. Acta Infologica. Advance online publication.

https://doi.org/10.26650/acin. 887367

\begin{abstract}
With the development of information technologies, traditional trading methods have also changed and the concept of e-commerce has emerged as a result of this change. In the field of e-commerce, which has a growing market share, in Turkey, there are several e-commerce sites that offer products and services in different categories. Within the scope of this study, the relationships between the frequency of shopping from e-commerce sites and different factors were examined, and at the same time, it was aimed to reveal the changing preferences depending on gender. For these purposes, a questionnaire was applied to 1176 users of e-commerce sites. Survey findings were analyzed with correlation, t-test and chi-square tests. As a result, different factors affecting the frequency of use of e-commerce sites and usage habits that differ according to gender groups have been revealed.
\end{abstract}

Keywords: e-commerce, e-commerce usage habits

ÖZ

Bilişim teknolojilerinin gelişmesi ile birlikte geleneksel ticaret yöntemleri de değişmiş ve bu değişimin sonucunda e-ticaret kavramı ortaya çıkmıştır. Türkiye'de büyümekte olan bir pazar payına e-ticaret alanında, farklı kategorilerde ürün ve hizmet sunan birçok e-ticaret sitesi faaliyet göstermektedir. Bu çalışma kapsamında e-ticaret sitelerinden yapılan alışveriş sıklığı ile farklı faktörler arasındaki ilişkiler incelenmiş aynı zamanda cinsiyete bağlı olarak değişen tercihlerin ortaya konması amaçlanmıştır. Bu amaçlar doğrultusunda 1176 kullanıcıya anket uygulanmıştır. Anket bulguları; korelasyon, t-test ve ki kare testleri ile analiz edilmiştir. Sonuç olarak, e-ticaret sitelerinin kullanım sıklığını etkileyen farklı faktörler ve cinsiyet gruplarına göre farklılaşan kullanım alışkanlıkları ortaya konmuştur.

Anahtar kelimeler: e-ticaret, e-ticaret kullanım alıșkanlıkları 


\section{INTRODUCTION}

Traditional business habits have been changing with the improvements of information technologies. With this change, the concept of electronic commerce (e-commerce), in which commercial transactions are carried out electronically, has emerged. E-commerce can be defined as buying and selling of products and services through the Internet. It also covers advertising, marketing, customer support, security, delivery, payment etc. (Laudon and Laudon, 2012). In a simple explanation made in "The Guide for E-Commerce" by Istanbul Chamber of Commerce, e-commerce is moving the commerce notion, which is basically buying and selling a product or a service into electronic environment (Küçükyılmazlar, 2006). Meaning that this type of commerce can be seen as shifting the traditional commerce methods to the Internet. E-commerce also lets other types of activities move into the Internet. Also, planning of production and creation of product chain, promotion, advertisement, informing, banking, custom clearance, order, keeping commerce records and marketing directly to the customers can be considered within the scope of e-commerce (Bucakl1, 2007). Laudon and Laudon (2012) state that e-commerce emerged with Netscape in 1995, when they accepted advertisements from big firms and had the idea that the Internet could be a new tool for advertising and selling. Since then, it can be said that the idea of e-commerce has kept being popular and wider. Ecommerce and the Internet helped its users to have a physical border-free environment where they can reach what they are looking for with one click without going to bazaars and shopping places in person. Users can see many alternatives at once and buy in a short time. It also gave firms new marketing and selling opportunities (K1ran, 2020). From a larger perspective, it has no physical geographical boundaries, it is global, and reduces intermediaries (Gedik, 2021). The factors that are stated here provide convenience to the customers compared to traditional commerce methods. Hatipoğlu and Altan (2021), state that, e-commerce has enabled the traditional business to achieve larger, faster, better and more economical results, and the impact of e-commerce has gone beyond commercial activity. The benefits that e-commerce can bring, were stated in the report of Kantarc1, Özalp, Sezginsoy, Özaşkınlı, and Cavlak (2017). According to the report, e-commerce; will reduce informality, increase productivity, enable the development of sectors related to information communication technologies, enable Small and medium-sized enterprises (SMEs) to compete with large companies due to the lack of some cost elements in the physical world, promoting products abroad can be made easily, quickly and with low costs, and will increase export potential (Kantarc1 et al., 2017). E-commerce can still be considered as a new concept but it keeps changing and improving each day. It provides advantages both to the users and providers. So that it became a convenient way of commerce and it is clear that it will continue to affect the way of commerce activities. In addition, it can be said that, since it requires no contact in terms of space and payment, and provides opportunities to find and compare the products, e-commerce activities made online shopping possible even in such an extraordinary situation like the Covid-19 pandemic (Gençyürek Erdoğan, 2020). Akpunar (2017) stated that the e-commerce phenomenon can be turned into an opportunity by making good use of the Internet enthusiasm of the young population in Turkey. In this context, looking at Turkey, it can be said that this type of trade has been widening nowadays as well. According to the report of "E-Commerce in Turkey 2019 Market Size" prepared by TÜBİSAD, e-commerce in Turkey had a tendency to grow in different categories between 2015-2019 (TÜBİSAD, 2019).

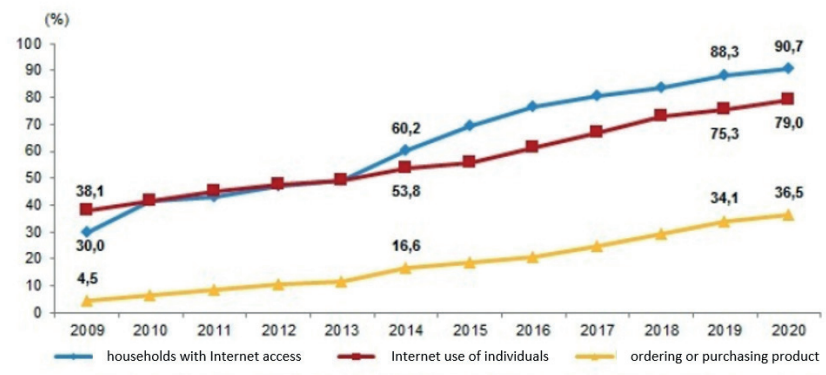

Figure 1. Basic Indicators of household technology usage, 2009-2020 (TÜİK, 2020)

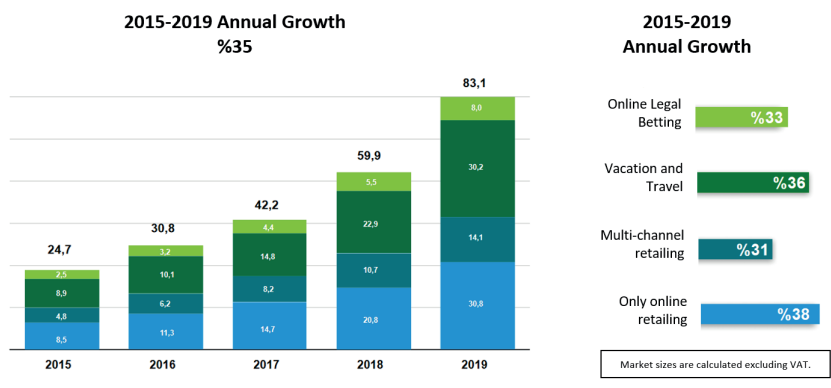

Figure 2. Size of E-Commerce Market in Turkey. (Billion TL) (TÜBİSAD, 2019) 
The reasons why online shopping is preferred by users were revealed by PwC in a research in 2016 (PwC, 2016). In the research, reasons to prefer online shopping for users in Turkey and in other countries were compared. While $36 \%$ of the users in Turkey prefer online shopping because it is easy, this rate is $47 \%$ in the global level. The proportion of those who prefer shopping online because it is cheaper is $43 \%$ globally and $56 \%$ in Turkey. $10 \%$ of the users in Turkey prefer online shopping due to other reasons while this rate is $8 \%$ globally. It can be said that pricing affects online shopping users in Turkey more than the convenience it provides. Considering the «Household Information Technologies (IT) Usage Survey» conducted by the Turkish Statistical Institute (TÜIK) together with the market growth rates in Figure 2, household's Internet access capability, individuals Internet usage, and the rate of ordering or purchasing products or services over the Internet, it is seen that they have an ever-increasing trend between 2009-2020. In this regard, it is thought that with the wider usage of the Internet and improvements in technologies, the reasons for choosing e-commerce and applications of e-commerce can widen their space. Within the scope of this study, the relationships between the frequency of shopping from e-commerce sites and different factors were examined, and at the same time, it aimed to reveal the changing preferences depending on gender. Research questions tested in the scope of this the study are given below:

$R Q_{1}$ : Does the frequency of shopping from e-commerce sites differ according to the reasons why users prefer e-commerce sites?

$R Q_{2}$ : Does the frequency of shopping from e-commerce sites differ according to the preferred payment types when shopping from ecommerce sites?

$R Q_{3}$ : Does the frequency of shopping from e-commerce sites differ according to the information sources that users consult to before purchasing products from e-commerce sites?

$R Q_{4}$ : Does the frequency of shopping from e-commerce sites differ according to the centers of e-commerce sites?

$R Q_{5}:$ Do the investigated different criteria differ according to gender?

$R Q_{6}:$ Do the preferred e-commerce sites differ according to gender?

$R Q_{7}:$ Do the preferred shipping companies differ according to gender?

$R Q_{8}:$ Is there a relationship between preference of e-commerce and gender?

$R Q_{9}:$ Is there a relationship between e-commerce categories and gender?

$R Q_{10}:$ Is there a relationship between preference of payment and gender?

$R Q_{11}$ : Is there a relationship between information sources that users consult to before purchasing products from e-commerce site and gender?

$R Q_{12}:$ It there a relationship between centers of e-commerce websites and gender?

\section{METHOD}

This study aims to examine the e-commerce habits of users. For this purpose, descriptive research design is followed and an online survey is used to collect data by using Google Forms. The questionnaire consists of 22 questions created by using different resources. The resources are as follows, "2017 Global Online Consumer Report” by KPMG (KPMG, 2017), "Brand growth through a cross-generational approach to consumer profiling” by Deloitte (Fedder, Shweta, and Upadhyaya, 2018), "Customer Profile and Consciousness Levels Research Report” (Güzel et al., 2018) shared by Republic of Turkey's Ministry of Commerce, "Online Shopping Consumer Behavior Research and Brand Comparison- E-commerce in Turkey" (Twentify, 2018) shared by Twentify, "E-Commerce as a Focus on Digital Market: Turkey's Place in the World, Present Status and Steps for the Future" (Deloitte and TÜSİAD, 2019) shared by TUSIAD, "Digital 2019 Turkey" (wearesocial and Hootsuite, 2019) published by Hootsuite and Wearesocial, "FMCG Trends in Turkey and E-Commerce" (Şekerel Erdoğan and Unutkan, 2019) created by Nielsen, "Online Monitor 2019" (HDE Handelsverband Deutschland, 2019) were used. The dataset used in this 
study is collected from 49 cities of Turkey with the participation of 1176 people. Haphazard sampling was used in the study. In order to analyze the data, the methods of descriptive statistics, correlation, regression, t-test and chi-square were used. The dataset was tested for normal distribution before analyzing it, and found that it is normally distributed. In addition, the Levene test was conducted to test the homogeneity of group variances for the t-test, and the obtained findings are shared in the next section.

\section{FINDINGS}

The $62.7 \%$ of participants $(n=737)$ are female while $37.3 \%$ of them $(n=439)$ are male. The $4.7 \%(n=55)$ of the participants aged under 18, 65.1\% $(n=766)$ aged between 19 and 25, 16.1\% $(n=189)$ aged between 26 and 35, 9.3\% ( $n=109)$ aged between 36 and 45, 3.2\% $(n=38)$ aged between 46 and 55, and 1.6\% $(n=19)$ aged above 55. Participants were from 49 different cities of Turkey; however, the majority of the participants $(68.1 \%, \mathrm{n}=801)$ live in Istanbul.

Table 1 shows the frequency of e-commerce websites usage by the participants. According to the table, Yemeksepeti and Trendyol, are used more than a few times in a month on average.

Table 1

\begin{tabular}{lll}
\multicolumn{2}{l}{ Average frequency of using } & E-Commerce websites \\
\hline Order & E-commerce Website & Mean \\
\hline 1 & Yemeksepeti & 2.331 \\
2 & Trendyol & 2.224 \\
3 & HepsiBurada & 1.929 \\
4 & Kitapyurdu & 1.713 \\
5 & n11 & 1.616 \\
6 & Gittigidiyor & 1.588 \\
7 & Getir & 1.554 \\
8 & Ciçeksepeti & 1.476 \\
9 & d\&r & 1.439 \\
10 & Sahibinden & 1.384 \\
11 & Migros Sanal Market & 1.378 \\
12 & Aliexpress & 1.352 \\
\hline
\end{tabular}

\begin{tabular}{lll}
\hline Order & E-commerce Website & Mean \\
\hline 13 & Banabi & 1.307 \\
14 & Amazon & 1.299 \\
15 & Boyner & 1.288 \\
16 & Watsons & 1.287 \\
17 & LCWaikiki & 1.274 \\
18 & Morhipo & 1.264 \\
19 & Teknosa & 1.243 \\
20 & Ebebek & 1.21 \\
21 & Carrefoursa & 1.167 \\
22 & PttAvm & 1.167 \\
23 & Bakkaldan & 1.139 \\
24 & Kapgel & 1.128 \\
\hline
\end{tabular}

Regression analysis is conducted among frequency of e-commerce, frequency of using e-commerce sites and the reasons for choosing them, however there is no meaningful result. According to the regression analysis findings, these variables do not directly affect e-commerce.

Correlation analysis is conducted to investigate whether there is a relationship among the e-commerce sites that the participants prefer. Table 2 shows the findings of four websites where a notable relation is observed as a result of correlation analysis. The results do not make much sense considering that these sites are the least visited ones.

Table 2

Correlation analysis of shopping sites

\begin{tabular}{lllll}
\hline & Carrefoursa & PttAvm & Bakkaldan & Kapgel \\
\hline Carrefoursa & 1 & 0.641306251 & 0.634520039 & 0.713037824 \\
PttAvm & 0.641306251 & 1 & 0.659759529 & 0.741361792 \\
Bakkaldan & 0.634520039 & 0.659759529 & 1 & 0.859151706 \\
Kapgel & 0.713037824 & 0.741361792 & 0.859151706 & 1 \\
\hline
\end{tabular}

T-test is conducted to determine whether there is a significant difference between frequency of e-commerce and different factors. The relationship between the frequency of shopping from e-commerce sites and the reasons for preferring e-commerce sites were examined in Table 3. It seems that people who prefer e-commerce more often than others, prefer e-commerce due to promotions and discounts, faster shopping, product options, and opportunity to read reviews before buying the product. 
Table 3

E-commerce frequency and e-commerce preference reasons ( $t$-test)

\begin{tabular}{lllll}
\hline $\begin{array}{l}\text { Research } \\
\text { question }\end{array}$ & E-commerce preference reason & p Values & Difference & $\begin{array}{l}\text { If there is a difference, type of the } \\
\text { relationship }\end{array}$ \\
\hline$R Q_{1} \cdot a$ & Promotions and Discounts & 0.01639 & Yes & Positive \\
$R Q_{1} \cdot b$ & Shopping faster & $5.389 \mathrm{e}-09$ & Yes & Positive \\
$R Q_{1} \cdot c$ & There are more product options & $3.66 \mathrm{e}-05$ & Yes & Positive \\
$R Q_{1} \cdot d$ & There are more payment options & 0.5782 & No & - \\
$R Q_{1} \cdot e$ & Price comparison possibility & 0.09441 & No & - \\
$R Q_{1} \cdot f$ & Reading reviews possibility before buying the product & $6.559 \mathrm{e}-06$ & Yes & Positive \\
$R Q_{1} \cdot g$ & The product I am looking for is not available in the city I am in & 0.2629 & No & - \\
$R Q_{1} \cdot h$ & Some products I bought are sold only online & 0.5854 & No & -
\end{tabular}

$R Q_{1}$ : The frequency of shopping from e-commerce sites differs according to the reasons why users prefer e-commerce sites.

Table 4 shows the relationship between the frequency of shopping from e-commerce sites and the preferred payment methods on these sites. It is observed that those who prefer credit card and BKM as payment method in e-commerce, shop online more frequently.

$R Q_{2}$ : The frequency of shopping from e-commerce sites differs according to the preferred payment types when shopping from e-commerce sites.

Table 4

E-commerce frequency and payment methods (t-test)

\begin{tabular}{|c|c|c|c|c|}
\hline Research question & Payment method & p Values & Difference & If there is a difference, type of the relationship \\
\hline$R Q_{2} \cdot a$ & Bank Card & 0.5576 & No & - \\
\hline$R Q_{2} \cdot b$ & Credit Card & $1.992 \mathrm{e}-07$ & Yes & Positive \\
\hline$R Q_{2} . c$ & EFT / Transfer & 0.8804 & No & - \\
\hline$R Q_{2} \cdot d$ & Cash on Delivery & 0.07145 & No & - \\
\hline$R Q_{2} \cdot e$ & BKM & 0.0007128 & Yes & Positive \\
\hline
\end{tabular}

Table 5 shows the relationship between the frequency of shopping from e-commerce sites and the sources of information consulted when purchasing products. It has been observed that users who pay attention to their previous experiences as a source of information shop more frequently. Moreover, users who prefer websites providing information about the product / service, shop more frequently.

$R Q_{3}:$ The frequency of shopping from e-commerce sites differs according to the information sources that users consult to before purchasing products from e-commerce sites.

Table 5

E-commerce frequency and the reasons for shopping from these sites (t-test)

\begin{tabular}{|c|c|c|c|c|}
\hline Research question & Information sources before purchasing a product & p Values & Difference & $\begin{array}{l}\text { If there is a difference, type of } \\
\text { the relationship }\end{array}$ \\
\hline$R Q_{3} \cdot a$ & Advertisements & 0.3066 & No & - \\
\hline$R Q_{3} \cdot b$ & Friend's Advices & 0.53 & No & - \\
\hline$R Q_{3} \cdot c$ & Sales Consultants & 0.267 & No & - \\
\hline$R Q_{3} \cdot d$ & Products Catalogs & 0.6051 & No & - \\
\hline$R Q_{3} \cdot e$ & Billboards, flyers, posters etc. & 0.7572 & No & - \\
\hline$R Q_{3} f$ & Television programs and expert advices & 0.814 & No & - \\
\hline$R Q_{3} \cdot g$ & Family Member's Advice & 0.3751 & No & - \\
\hline$R Q_{3} \cdot h$ & Information Labels on the Product & 0.2845 & No & - \\
\hline$R Q_{3} \cdot i$ & Old Experiences & 0.001752 & Yes & Positive \\
\hline$R Q_{3} j$ & Websites providing information about the product / services & $5.414 \mathrm{e}-05$ & Yes & Positive \\
\hline
\end{tabular}


Table 6 shows the relationship between the frequency of shopping from e-commerce sites and being based in Turkey or having a physical store. It is found that there is no relationship between frequency of using e-commerce and the sites being based in Turkey. It is also observed that there is a significant negative relationship between the sitess having a physical store and the frequency of e-commerce. In short, the fact that the company has a physical store has an adverse effect on e-commerce frequency.

$R Q_{4}$ : The frequency of shopping from e-commerce sites differs according to the centers of e-commerce sites.

Table 6

E-commerce frequency and centre of e-commerce website or having a physical store ( $t$-test)

\begin{tabular}{lllll}
\hline Research question & $\begin{array}{l}\text { Centre of e-commerce website and having } \\
\text { a physical store }\end{array}$ & $\mathbf{p}$ Values & Difference & If there is a difference, type of the relationship \\
\hline$R Q_{4} \cdot a$ & The importance of being based in Turkey & 0.1868 & No & Not \\
$R Q_{4} \cdot b$ & The importance of having a physical store & $4.579 \mathrm{e}-07$ & Yes & Positive \\
\hline
\end{tabular}

According to the results shown in Table 7, the number of men visiting e-commerce sites is higher than women. However, considering the frequency of e-commerce, it is observed that there is no notable difference between these two groups. At the same time, there is no difference between the groups in terms of the reasons to prefer e-commerce. According to the shopping patterns, which implies that shopping decisions are affected by the campaigns and special advantages offered by the sites, women expect more from shopping sites than men.

$R Q_{5}$ : Investigated different criteria differ according to gender.

Table 7

Gender and other criterions regarding e-commerce (t-test)

\begin{tabular}{lllll}
\hline Research question & Criterions & p Values & Difference & If there is a difference, group with a higher mean \\
\hline$R Q_{5} \cdot a$ & Websites visiting frequency & 0.03379 & Yes & Men \\
$R Q_{5} \cdot b$ & E-Commerce frequency & 0.5716 & No & - \\
$R Q_{5} \cdot c$ & E-Commerce reason & 0.0678 & No & - \\
$R Q_{5} \cdot d$ & Shopping Pattern & 0.004133 & Yes & Women \\
$R Q_{5} \cdot e$ & Search before shopping & 0.1547 & No & - \\
\hline
\end{tabular}

$R Q_{6}:$ Preferred e-commerce sites differ according to gender.

$R Q_{7}:$ Preferred shipping companies differ according to gender.

It is also examined whether there is a difference between shopping sites and preferred shipping companies with regard to gender (Table 8). The shopping sites and preferred shipping companies show statistically significant differences regarding gender. HepsiBurada, Gittigidiyor, Sahibinden, n11, Aliexpress, Amazon, Teknosa, PttAvm, Getir, Banabi sites are preferred more by men. Trendyol, Kitapyurdu, Çiçeksepeti, Watsons sites are preferred more by women. In terms of shipping companies, while Sürat Kargo and UPS Cargo are preferred more by men, women prefer Yurtiçi Kargo. There is no difference between the genders regarding the preference of other sites and shipping companies. 


\begin{tabular}{|c|c|c|c|c|c|c|c|c|c|}
\hline 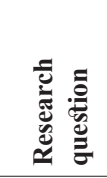 & 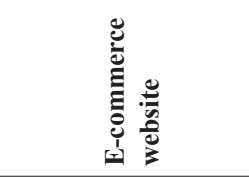 & $\begin{array}{l}\frac{\mathscr{e}}{\tilde{E}} \\
\frac{\pi}{2} \\
2\end{array}$ & : & $\begin{array}{l}\text { If there is a } \\
\text { difference, } \\
\text { group with a } \\
\text { higher mean }\end{array}$ & 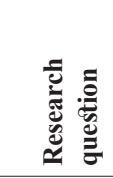 & 总咅 & $\begin{array}{l}\frac{\mathscr{b}}{\pi} \\
\frac{\pi}{2} \\
2\end{array}$ & : & $\begin{array}{l}\text { If there is a } \\
\text { difference, group } \\
\text { with a higher } \\
\text { mean }\end{array}$ \\
\hline$R Q_{6} a$ & HepsiBurada & 0 & Yes & Men & $R Q_{7} \cdot a$ & MNG Kargo & 0.9208 & No & - \\
\hline$R Q_{6} b$ & Trendyol & $2.705 \mathrm{e}-11$ & Yes & Women & $R Q_{7} \cdot b$ & Sürat Kargo & 0.01352 & Yes & Men \\
\hline$R Q_{6} c$ & Gittigidiyor & $8.809 \mathrm{e}-07$ & Yes & Men & $R Q_{7} \cdot c$ & Yurtiçi Kargo & 0.0186 & Yes & Women \\
\hline$R Q_{6} d$ & Sahibinden & $2.591 \mathrm{e}-10$ & Yes & Men & $R Q_{7} \cdot d$ & PTT Kargo & 0.724 & No & - \\
\hline$R Q_{6} e$ & n11 & $1.645 \mathrm{e}-08$ & Yes & Men & $R Q_{7} \cdot e$ & UPS & $2.801 \mathrm{e}-05$ & Yes & Men \\
\hline$R Q_{6} f$ & Yemeksepeti & 0.4397 & No & - & & & & & \\
\hline$R Q_{6} g$ & Aliexpress & $6.883 \mathrm{e}-06$ & Yes & Men & & & & & \\
\hline$R Q_{6} h$ & Migros sanal market & 0.6606 & No & - & & & & & \\
\hline$R Q_{6} i$ & Ebebek & 0.2475 & No & - & & & & & \\
\hline$R Q_{6} j$ & Amazon & $1.193 \mathrm{e}-05$ & Yes & Men & & & & & \\
\hline$R Q_{6} \cdot k$ & Teknosa & 0.007072 & Yes & Men & & & & & \\
\hline$R Q_{6} l$ & Kitapyurdu & 0.0006208 & Yes & Women & & & & & \\
\hline$R Q_{6} \cdot m$ & Morhipo & 0.1331 & No & - & & & & & \\
\hline$R Q_{6} n$ & Çiçeksepeti & 0.02663 & Yes & Women & & & & & \\
\hline$R Q_{6}$. & D\&r & 0.1599 & No & - & & & & & \\
\hline$R Q_{6} p$ & Watsons & $3.893 \mathrm{e}-07$ & Yes & Women & & & & & \\
\hline$R Q_{6} q$ & Lcwaikiki & 0.3989 & No & - & & & & & \\
\hline$R Q_{6} r$ & Boyner & 0.9653 & No & - & & & & & \\
\hline$R Q_{6} s$ & Carrefoursa & 0.8025 & No & - & & & & & \\
\hline$R Q_{6} \cdot t$ & PttAvm & 0.04094 & Yes & Men & & & & & \\
\hline$R Q_{6} u$ & Getir & 0.01444 & Yes & Men & & & & & \\
\hline$R Q_{6} v$ & Banabi & 0.00987 & Yes & Men & & & & & \\
\hline$R Q_{6} \cdot w$ & Bakkaldan & 0.09451 & No & - & & & & & \\
\hline$R Q_{6} x$ & Kapgel & 0.08541 & No & - & & & & & \\
\hline
\end{tabular}

The chi-square test is used to examine whether there is a significant difference between different factors and gender groups. The results of these examinations can be seen in Table 9 below. It has been revealed that there is a significant difference between men and women due to e-commerce preference reasons. Men prefer e-commerce more than women because of the promotions and discounts, price comparison possibility and opportunity to read reviews before purchasing the product. When the categories of shopping are examined, it is seen that there is a notable difference between women and men in certain categories. Digital Music / Digital Film / Digital Game, fast-moving consumer goods, Mother / Baby / Toys, Household Goods, Automobile Accessories, Travel (Transportation / Accommodation), and Sports and Cultural Activity Tickets categories are preferred more by men. Women shop more in the Book, Personal Care \& Cosmetics, Clothing / Shoes, and Jewelry categories. Looking at the preferred payment methods in e-commerce, it is seen that women prefer the debit card, while men prefer the credit card, EFT / Transfer and BKM. Resources consulted before purchasing differ according to gender groups. Women seem to consult advertisements, Product catalogues and information labels on the products. Moreover, women use their own previous experiences before purchasing. On the other hand, men use other websites that give information about products / services relatively more frequently. Whether an e-commerce site is based in Turkey is more important for women. Besides, having a physical store seem to be more important for women too.

$R Q_{8}:$ There is a relationship between preference of e-commerce and gender.

$R Q_{9}:$ There is a relationship between e-commerce categories and gender.

$R Q_{10}:$ There is a relationship between preference of payment and gender.

$R Q_{11}$ : There is a relationship between information sources that users consult to before purchasing products from e-commerce site and gender.

$R Q_{12}:$ There is a relationship between centers of e-commerce websites and gender. 
Table 9

Gender and e-commerce usage (chi-square)

\begin{tabular}{|c|c|c|c|c|}
\hline Research question & E-commerce preference reasons & p Values & Difference & $\begin{array}{l}\text { If there is a difference, } \\
\text { group with a higher mean }\end{array}$ \\
\hline$R Q_{8} \cdot a$ & Promotions and Discounts & $1.077269 \mathrm{e}-05$ & Yes & Men \\
\hline$R Q_{8} \cdot b$ & Shopping faster & 0.7692154 & No & - \\
\hline$R Q_{8} \cdot c$ & There are more product options & 0.2401926 & No & - \\
\hline$R Q_{8} \cdot d$ & There are more payment options & 0.07216846 & No & - \\
\hline$R Q_{8} \cdot e$ & Price comparison possibility & $5.097359 \mathrm{e}-06$ & Yes & Men \\
\hline$R Q_{8} f$ & Reading reviews possibility before buying the product & 0.0007583622 & Yes & Men \\
\hline$R Q_{8} \cdot g$ & The product I am looking for is not available in the city I am in & 0.2033556 & No & - \\
\hline$R Q_{8} \cdot h$ & Some products I bought are sold only online & 0.06186989 & No & - \\
\hline Research question & Categories of online shopping & p Values & Difference & $\begin{array}{l}\text { If there is a difference, } \\
\text { group with a higher mean }\end{array}$ \\
\hline$R Q_{9} \cdot a$ & Food Order & 0.6795326 & No & - \\
\hline$R Q_{9} \cdot b$ & Music / Film / Hobby / Game & 0.07769071 & No & - \\
\hline$R Q_{9} \cdot c$ & Digital Music / Digital Film / Digital Game & $3.419981 \mathrm{e}-09$ & Yes & Men \\
\hline$R Q_{9} \cdot d$ & Book & $4.082813 \mathrm{e}-13$ & Yes & Women \\
\hline$R Q_{9} \cdot e$ & Personal Care \& Cosmetics & $7.879339 \mathrm{e}-05$ & Yes & Women \\
\hline$R Q_{9} f$ & Fast-moving consumer goods (Food, Beverage etc.) & $2.338397 \mathrm{e}-10$ & Yes & Men \\
\hline$R Q_{9} \cdot g$ & Technology / Electronics & 0.06177522 & No & - \\
\hline$R Q_{9} \cdot h$ & Clothing / Shoes & $7.923153 \mathrm{e}-37$ & Yes & Women \\
\hline$R Q_{9} \cdot i$ & Mother / Baby / Toy & $2.071815 \mathrm{e}-20$ & Yes & Men \\
\hline$R Q_{9} j$ & Pet Products & 0.6605769 & No & - \\
\hline$R Q_{9} \cdot k$ & Online Education & 0.5488648 & No & - \\
\hline$R Q_{9} \cdot l$ & Household Goods & 0.0129924 & Yes & Men \\
\hline$R Q_{9} \cdot m$ & $\begin{array}{l}\text { Flowers / Chocolate / Online Education / Jewelry / Pet Products / } \\
\text { Other }\end{array}$ & 0.4560453 & No & - \\
\hline$R Q_{9} \cdot n$ & Car Accessories & 0.03177681 & Yes & Men \\
\hline$R Q_{9} \cdot o$ & Travel (Transportation / Accommodation) & $6.594161 \mathrm{e}-12$ & Yes & Men \\
\hline$R Q_{9} \cdot p$ & Sports and Cultural Activity Tickets & 0.004414793 & Yes & Men \\
\hline$R Q_{9} \cdot q$ & Financial Services / Insurance Purchase & 0.08395311 & No & - \\
\hline$R Q_{9} \cdot r$ & Jewelry & $2.98725 \mathrm{e}-06$ & Yes & Women \\
\hline Research question & Payment type & p Values & Difference & $\begin{array}{l}\text { If there is a difference, } \\
\text { group with a higher mean }\end{array}$ \\
\hline$R Q_{10} \cdot a$ & Bank Card & $6.868541 \mathrm{e}-06$ & Yes & Women \\
\hline$R Q_{10} \cdot b$ & Credit Card & 0.0005555569 & Yes & Men \\
\hline$R Q_{10} \cdot c$ & EFT / Transfer & $3.958431 \mathrm{e}-08$ & Yes & Men \\
\hline$R Q_{10} \cdot d$ & Cash on Delivery & 0.925653 & No & - \\
\hline$R Q_{10} \cdot e$ & $\mathrm{BKM}$ & 0.00135785 & Yes & Men \\
\hline Research question & Information sources before purchasing a product & p Values & Difference & $\begin{array}{l}\text { If there is a difference, } \\
\text { group with a higher mean }\end{array}$ \\
\hline$R Q_{11} \cdot a$ & Advertisements & 0.008604957 & Yes & Women \\
\hline$R Q_{11} \cdot b$ & Friend's Advices & 0.3635637 & No & - \\
\hline$R Q_{11} \cdot c$ & Sales Consultants & 0.0002123274 & Yes & Women \\
\hline$R Q_{11} \cdot d$ & Products Catalogs & 0.06059267 & No & Not \\
\hline$R Q_{11} \cdot e$ & Billboards, flyers, posters etc. & 0.5959363 & No & - \\
\hline$R Q_{11} f$ & Television programs and expert advices & 0.3015192 & No & - \\
\hline$R Q_{11} \cdot g$ & Family Member's Advice & 0.3986611 & No & - \\
\hline$R Q_{11} \cdot h$ & Information Labels on the Product & $1.286374 \mathrm{e}-09$ & Yes & Women \\
\hline$R Q_{11} \cdot i$ & Old Experiences & 0.002007309 & Yes & Women \\
\hline$R Q_{11} j$ & Websites providing information about the product / service & 0.03427452 & Yes & Men \\
\hline Research question & Centre of e-commerce website and physical store & p Values & Difference & $\begin{array}{l}\text { If there is a difference, } \\
\text { group with a higher mean }\end{array}$ \\
\hline$R Q_{12} \cdot a$ & The importance of being based in Turkey & 0.0004916165 & Yes & Women \\
\hline$R Q_{12} \cdot b$ & The importance of having a physical store & $1.864215 \mathrm{e}-05$ & Yes & Women \\
\hline
\end{tabular}




\section{DISCUSSION AND CONCLUSION}

In general, Yemeksepeti, Trendyol and HepsiBurada became the most popular e-commerce sites in a sample where women participants are in high numbers. The participants do not have a solid tendency to shop from Carrefoursa, PttAvm, Bakkaldan and Kapgel websites which are put into the survey assuming that they are popular websites.

Promotions and discounts, more product options and reading reviews before buying the product affect how often people use e-commerce. It is seen that e-commerce services and products become more appealing because of today's fast and corrosive lifestyle especially in big cities and the difficulty of being physically mobile. When women and men are compared, it is seen that men prefer e-commerce more than women in terms of the factors of the availability of promotions and discounts, the ability to compare prices and to read other reviews about the product. Several reports along with "Driving force of economy in digital World: E-Commerce" report (Kantarc1 et al., 2017) by TÜSİAD show that comparison of price is an important criterion, however the results of this study show otherwise. However, being able to compare prices of the products is not seen as an advantage of e-commerce.

It has emerged as an expected result that the payment methods preferred by users on e-commerce sites and the frequency of e-commerce are related. Considering general usage habits, credit cards are widely used for payment. The partial payments offered in the promotion and sales categories could be promoting the usage of credit cards more, and it is thought that BKM is seen as a secure payment method by consumers. Consumers who use credit cards and BKM in online shopping are more involved with e-commerce. It can be because of their trust on e-commerce, so that they can easily share their card information. This results in more shopping. It is observed that women tend to use more traditional payment methods such as debit cards, while men use credit cards, EFT/transfer and BKM.

Consumers who often shop online tend to search websites which give information about the product/service and look at their previous experiences before purchasing it. Besides, the results show that advertisement, product catalogues, information labels on the product and previous experiences are widely used as sources for women when websites providing information about the product / service are used by men before purchasing a good or service. In this context, it is seen that the resources that women examine before buying are more diverse.

While the lack of physical stores of sites offering e-commerce services via Internet increases the frequency of shopping at websites, women find it more important than men that the center of the site is in Turkey and have a physical store. In general, different factors such as the availability of more options without any physical effort, the availability of campaigns offered, and ease of payment may make shopping on e-commerce sites attractive for users. At this point, the lack of a physical store emerges as a factor that positively affects the shopping frequency. From the perspective of gender, it can be said that women associate the websites centered in Turkey and the presence of a physical store with the reliability of related websites.

Although men visit e-commerce sites more frequently, there is no difference between men and women in terms of frequency of e-commerce. However, there is a significant difference between men and women according to the shopping pattern criterion, which expresses the campaign and special advantages offered. In other words, it can be said that factors such as following campaign days, free shipping and special offers are more important for women. Based on this, it is thought that different options that attract the attention of women and men can be created by the sites.

In the analysis made according to gender, it is seen that women use Yurtiçi Kargo more, while men use Sürat Kargo and UPS more. It is not surprising that men use general shopping sites such as Hepsiburada, Gittigidiyor, Sahibinden, n11, and women use Trendyol, that sells more clothing and make-up materials. Considering that all these sites have served in each otherss fields over time, it can be said that this did not find much response on the consumer side, and it is the same today as it was used before.

According to other analysis, it has been observed that promotions, possibility of price comparison and finding product reviews are the reasons for e-commerce for men. In addition to personal expenses such as digital products, and sports / cultural activities, men meet the collective needs of families such as fast-moving consumer goods, household goods, automobile 
accessories, travel, mothers and babies care, and toys on the Internet, women can buy personal products such as books, personal care products and jewelry on the Internet. It can be said that the shopping categories preferred by men and women are compatible with the general perceptions and attitudes in the society, however, it is not a generalizable finding.

What emerges in general is that women do more research, and they are more likely to avoid risk compared to men. While the reliability of the credit card has been evident in recent years, it is still less commonly used by women. While men are open to more innovations in shipping and websites, women tend to use the tried, reliable and classic ways. Both groups cannot respond to the innovations of the sites, and use the sites for the same purpose they used to use.

There are several limitations encountered during this study. The age of samples is too young, the number of women is higher than the average of Turkey and it does not cover all the cities of Turkey. It is thought that the findings obtained as the results of this study revealed some of the factors affecting e-commerce usage and shopping frequency. More detailed research can be conducted on the factors affecting the purchasing decision of the individuals and the scope of the research conducted by the individuals before purchasing in order to conduct more comprehensive research in future studies.

Hakem Değerlendirmesi: Dıș bağımsız.

Çıkar Çatışması: Yazarlar çıkar çatışması bildirmemiştir.

Etik Komite Onayı: Bu çalıșma için etik komite onayı Marmara Üniversitesi Sosyal Bilimler Araștırma Etik Kurulu'ndan alınmıștır. (2021-06/04)

Yazar Katkıları: Çalışma Konsepti/Tasarım-S.K., B.A.; Veri Toplama- B.A.; Veri Analizi/Yorumlama-S.K., B.A., İ.E.E.; Yazı Taslağı- B.A., İ.E.E;İçeriğin Eleştirel İncelemesi-

S.K., İ.E.E.; Son Onay ve Sorumluluk- S.K., B.A., İ.E.E.

Finansal Destek: Yazarlar bu çalışma için finansal destek almadığını beyan etmiştir.

Peer-review: Externally peer-reviewed.

Conflict of Interest: The authors have no conflict of interest to declare.

Ethics Committee Approval: This study was approved by the Marmara University Social Sciences Research Ethics Committee. (2021-06/04)

Author Contributions: Conception/Design of Study- S.K., B.A.; Data Acquisition- B.A.; Data Analysis/Interpretation- S.K., B.A., I.E.E.; Drafting Manuscript- B.A., İ.E.E.; Critical Revision of Manuscript- S.K., İ.E.E.;Final Approval and Accountability- S.K., B.A., İ.E.E.

Grant Support: The authors declared that this study has received no financial support.

\section{References/Kaynaklar}

Akpunar, E. N. (2017). Türkiye>de elektronik dış ticaretin gelişimi ve istihdam ilişkisi. Harran Educational Journal, 2(2), 18-32. doi:10.22596/2017.0202.18.32 Bucakl1, A. T. (2007). Elektronik ticaret. İstanbul: Kadir Has Üniversitesi.

Deloitte, \& TÜSİAD. (2019). E-Ticaretin gelişimi, sınırların aşılması ve yeni normlar. TÜSİAD.

Fedder, C., Shweta, J., \& Upadhyaya, J. (2018). Brand growth through a cross-generational approach to consumer profiling. Deloitte Insights.

Gedik, Y. (2021). E-Ticaret: Teorik bir çerçeve. Ankara Üniversitesi Sosyal Bilimler Dergisi, 12(1), 184-198. doi:10.33537/sobild.2021.12.1.16

Gençyürek Erdoğan, M. (2020). Covid-19 döneminde e-ticaret ve dijital reklam yatırımları. Selçuk İletişim Dergisi, 13(3), 1296-1318. doi:10.18094/ JOSC.776605

Güzel, Y., İpek, G., Yıldırım Yılmaz, T., Babaoğul, M., Şener, A., Buğday, E. B., \& Yücel, S. (2018). Customer profile and consciousness levels research report. Türkiye Cumhuriyeti Ticaret Bakanlığı.

Hatipoğlu, C., \& Altan, İ. M. (2021). Türkiye〉de e-ticaret hizmetlerinin moora yöntemi ile incelenmesi. Dumlupınar Üniversitesi Sosyal Bilimler Dergisi, 68, 372-383. doi:10.51290/dpusbe. 875064

HDE Handelsverband Deutschland. (2019). Online monitor. HDE Handelsverband Deutschland.

Kantarcı, Ö., Özalp, M., Sezginsoy, C., Özaşkınlı, O., \& Cavlak, C. (2017). Dijitalleşen dünyada ekonominin itici gücü: E-ticaret. İstanbul: TÜSİAD Türk Sanayicileri ve İş İnsanları Derneği.

Kiran, S. (2020). Impact of social network use in Turkey on e-commerce based on Facebook case. International Journal of Research and Scientific Innovation (IJRSI), 7(3), 160-167.

KPMG. (2017). The truth about online consumers 2017 global online consumer report. KPMG.

Küçükyılmazlar, A. (2006). Elektronik ticaret rehberi. İstanbul: İstanbul Ticaret Odası.

Laudon, K. C., \& Laudon, J. P. (2012). Essentials of management information systems (10 ed.). New Jersey, USA: Pearson.

PwC. (2016). Total retail survey 2016. PwC.

Şekerel Erdoğan, D., \& Unutkan, İ. (2019). Türkiyesde FMCG trendleri ve e-ticaret. Nielsen.

TÜBİSAD. (2019). TÜBİSAD e-ticaret 2019 pazar büyüklüğü raporu. İstanbul: TÜBİSAD Bilişim Sanayicileri Derneği.

TÜİK. (2020). Hanehalkı bilişim teknolojileri (BT) kullanım araştırması. TÜİK.

Twentify. (2018). Türkiyède e-ticaret: Çevrimiçi alışverişte tüketici davranışları araştırması ve marka karşılaştırması. Twentify.

wearesocial, \& Hootsuite. (2019). Digital 2019 Turkey. we are social, Hootsuite. 